\title{
Recurrent scar endometriosis developing in the episiotomy
}

\section{Epizyotomi içinde gelişen tekrarlayan skar endometriozisi}

\author{
Esengül TÜRKYILMAZ ${ }^{1}$, Gökhan KILIC ${ }^{1}$, Fatma Doga OCAL ${ }^{3}$, Seda MARALI ${ }^{4}$, Ayse Filiz YAVUZ AVSAR ${ }^{2}$
}

\begin{abstract}
This case report presents a patient with recurrent endometriotic lesion which occurred in the episiotomy scar. The patient who was operated due to episiotomy scar endometriosis one year ago applied to our outpatient clinic with cyclic pain and swelling especially during menstrual periods which started on the same area. The mass ingrained approximately $2.5 \mathrm{~cm}$ deep from the surface, which localized on the episiotomy scar, was accessed and circumferentially excised. In the pathological examination, tissue which embedded into the fibro-adipose tissues was consistent with the diagnosis of endometriosis. Increased steroidogenic acute regulatory protein production mediated by prostaglandin E2 receptor and aromatase enzymes provide continuity of the endometriotic cells which were implanted during the vaginal birth under the effect of local hiperestrogenism. The genetic predisposition probably increases the tendency of recurrence of endometriotic lesions. These two possible mechanisms may be considered to be responsible for current case.
\end{abstract}

Key words: Endometriosis, episiotomy, genetic predisposition öz

Bu vaka epizyotomi skarında meydana gelen tekrarlayan derin endometriozisli hastayı sunmaktadır. Bir yıl önce epizyotomi skarında oluşan endometriozis nedeniyle opere olan hasta aynı bölgede başlayan, özellikle menstruasyon döneminde olan şişlik ve ağrı yakınması ile polikliniğimize başvurdu. Epizyotomi skarında lokalize olan, yüzeyden $2,5 \mathrm{~cm}$ derinde gömülü kitleye ulaşıldı ve çepeçevre eksize edildi. Patolojik incelemede fibroadipoz doku içine gömülü endometriozis ile uyumlu doku tespit edildi. Prostoglandin E2 aracılığıyla seviyeleri artan steroidogenik akut regulatuar protein ve aromataz enzimleri lokal hiperestrogenizm ile vajinal doğum sırasında implante olan endometriotik hücrelerin devamlılığını sağlar. Genetik yatkınlık olasılıkla endometriotik lezyonların tekrarlamaya eğilimini arttırır. Bu ikisi bu vaka için olası mekanizmalardır.

Anahtar kelimeler: Endometriyozis, epizyotomi, genetik yatkınlık

\section{INTRODUCTION}

Endometriosis is a benign gynaecological condition in which normal endometrial glands and stroma are localized outside the uterus. Endometriosis develops mostly in ovaries, peritoneum, pouch of Douglas and uterosacral ligaments ${ }^{1}$. However, incisional endometriosis as a result of recurrent caesarean sections laparoscopic surgery and also endometriosis on scars of trocar site have been reported. Also, literature reveals cases of episiotomy scar endometriosis developing on the scars of episiotomy incision performed during vaginal birth ${ }^{2,3}$. Laadi et al. ${ }^{4}$ have reported the case of deep endometriosis developing in the episio- tomy scar. There are case reports showing endometriotic nodules recurring on the episiotomy scar ${ }^{5,6}$.

The present case of deeply localized endometriosis with a family history which differs from many others in the literature has been reported because of its many characteristic features, its formation on the episiotomy scar, and its recurrent nature.

\section{CASE PRESENTATION}

The patient aged 33 years, with gravida 2 and parity 2 applied to an outpatient clinic with pain especially during menstrual periods which started on the epi-

Received: 19.02 .2016

Accepted: 05.04.2016

${ }^{1}$ Department of Gynecology and Obstetrics, Atatürk Training and Research Hospital, Ankara, Turkey

${ }^{2}$ Department of Gynecology and Obstetrics, Yildrim Beyazit University, Ankara, Turkey

${ }^{3}$ Department of Gynecology and Obstetrics, Doktor Sami Ulus Hospital, Ankara, Turkey

${ }^{4}$ Department of Pathology, Atatürk Training and Research Hospital, Ankara, Turkey

Yazışma adresi: Esengül Türkyılmaz, Department of Gynecology and Obstetrics, Ataturk Training and Research Hospital, Ankara, Turkey

e-mail: turkyilmaz06@yahoo.com 
siotomy scar 2 years after the last vaginal birth. The histopathology test result of the patient's specimen which was cut from the mass lesion was consistent with endometriosis.

Cyclic pain and swelling started one year later exactly on the same location and the patient was requested to continue her oral contraceptives. During the physical examination of the patient who applied to our outpatient clinic with intractable complaints, an approximately $2 \times 3 \mathrm{~cm}$ rigid, nodular, painful mass which was embedded deeply in episiotomy scar was palpated. The mass ingrained approximately $2.5 \mathrm{~cm}$ deep from the surface of the episiotomy scar, was accessed and circumferentially excised under general anaesthesia. In the pathological examination, it is shown that excised tissue is consistent with endometriosis and embedded into the fibro-adipose tissues.

Location, depth and association of the mass with

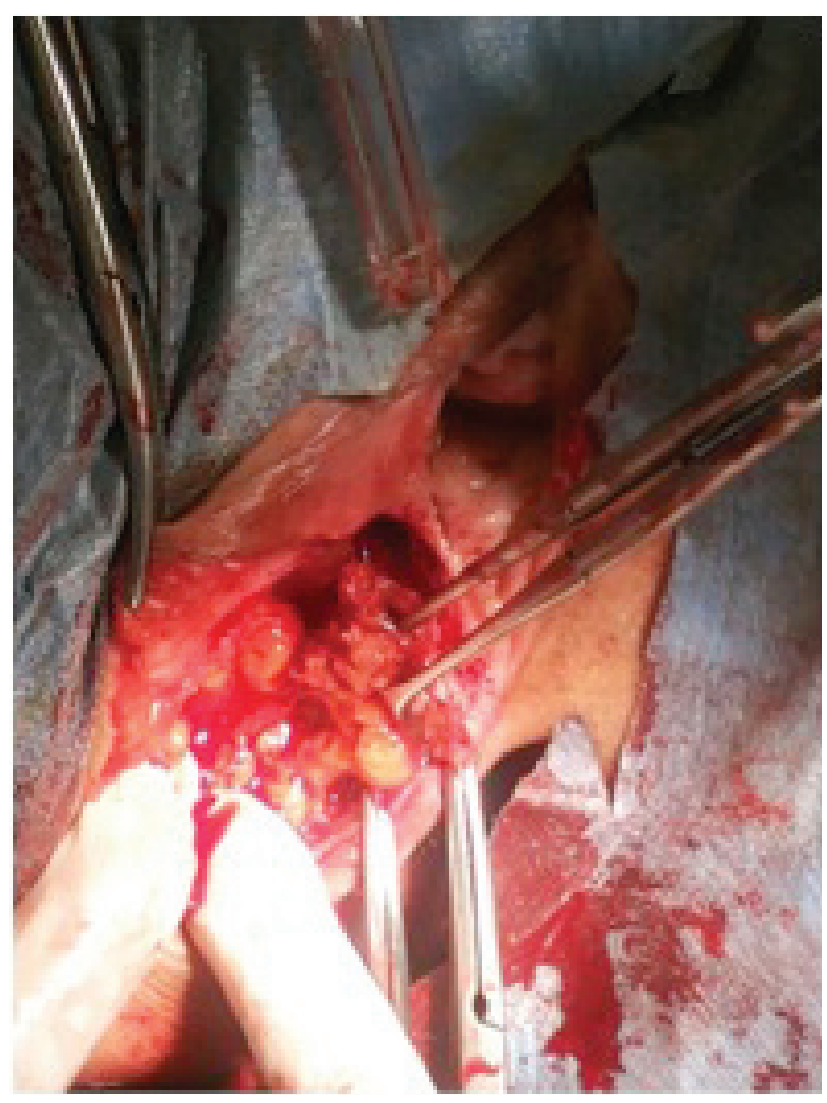

Figure 1. The localization, depth and association with the adjacent anatomic structures of the mass. the adjacent anatomic structures of the are shown in Figure 1. Macroscopic appearance and size of the excised mass is shown in Figure 2. Hematoxylin-eosin staining of the histopathologic preparation is shown in Figure $3(1 \times 10)$.

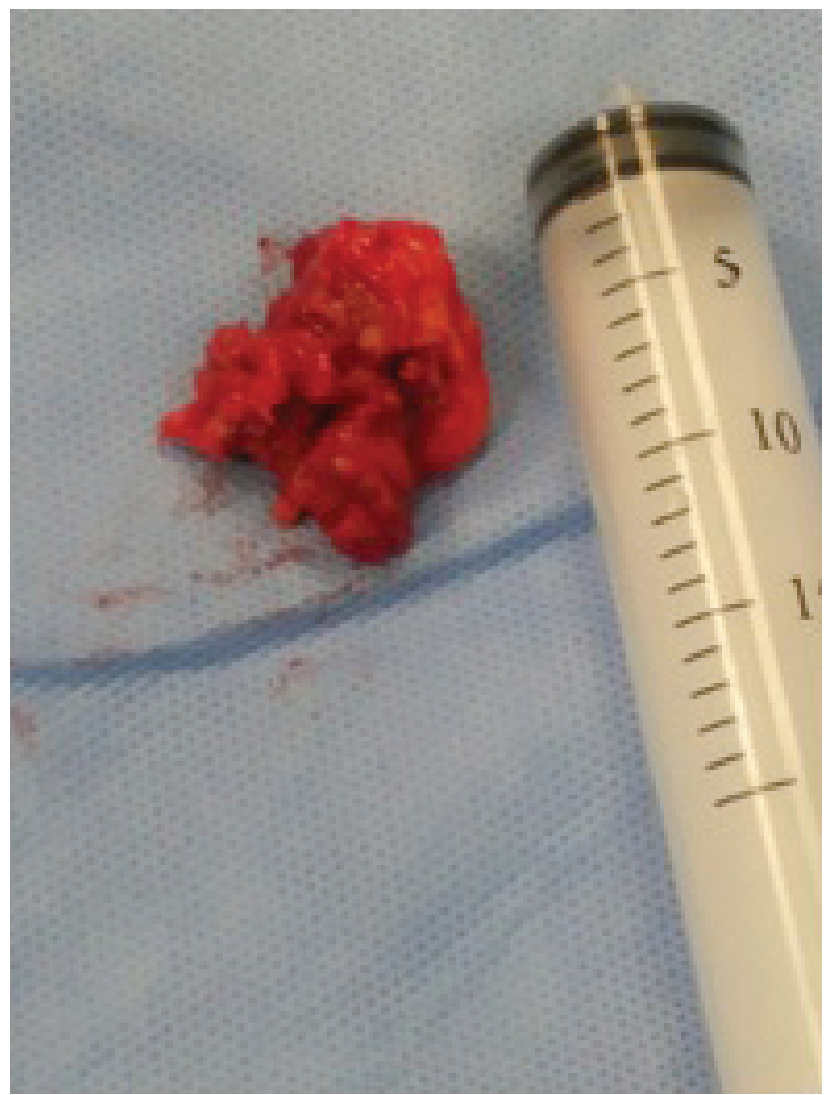

Figure 2. Macroscopic appearance and size of the excised mass.

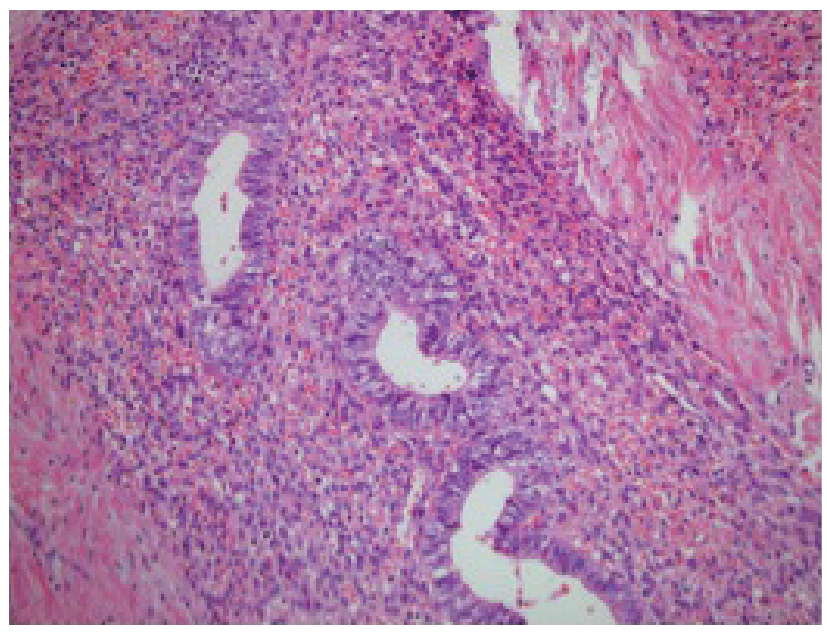

Figure 3. Hematoxylin eosin staining of the pathologic preparation (1X10). 
A previous pelvic endometriosis and infertility history of the patient was not present. Sister of the patient had history of invitro fertilization treatment due to infertility and laparoscopic operation due to endometrioma. Informed consent was obtained from the patient before the case report was written.

\section{DISCUSSION}

Endometriosis is a benign gynecological condition in which normal endometrial glands and stroma are localized outside of the uterus. While hormonal dependency theory is considered to explain pelvic endometriosis cases, different theories have been formulated to explain cases of extrapelvic endometriosis.

It is thought that incisional endometriosis occurs after direct inoculation of the endometrial cells into the subcutaneous tissue of the abdominal wall and sometimes into the rectus muscle plans ${ }^{7}$. In most of the patients who have incisional endometriosis, an evidence for the presence of endometriosis is not detected. This supports the theory of endometrial cell inoculation spreading during the surgery. The theory of implanting endometrial cells into the episiotomy scar is also thought for the patients who have endometriosis in the episiotomy scar but without any evidence of pelvic or extra-pelvic endometriosis.

The scar endometriosis can imitate incisional hernia when it is on the cesarean incision line and can imitate perianal abscess when it is on the perineum. The common trait of all these types of endometriosis is to cause increased swelling and pain especially during the menstrual period.

Endometriosis was thought as the preliminary preoperative diagnosis because the current patient had previous history of endometriosis excised from the episiotomy scar and her symptoms intensified during menstrual periods. Ultrasonography, computerized tomography and magnetic resonance imaging are useful in the diagnosis of scar endometriosis as in the pelvic endometriosis. The definitive diagnosis was established after the histopathological examination of the excised mass.

It is noteworthy that although many women have given vaginal birth, endometriosis on the episiotomy scar is seen in only some of the women who had not been diagnosed as having pelvic endometriosis. A set of mechanisms are responsible for the adherence, growth, and maintenance of the endometriotic cells after they implanted into the episiotomy scar. It has been shown that endometriotic stromal cells express Prostaglandin E2 (PGE2) receptor. PGE2 receptor increases the cyclic AMP (cAMP) production. Cyclic AMP is responsible from the production of steroidogenic acute regulatory protein (STAR) and cytochrome P450, family 19 , subfamily A, and polypeptide 1 (CYP19A1). Increased STAR production by PGE2 receptor and the level of aromatase provide continuity of the endometriotic cells with local hiperestrogenism ${ }^{8,9}$. This mechanism was shown in Scheme 1.
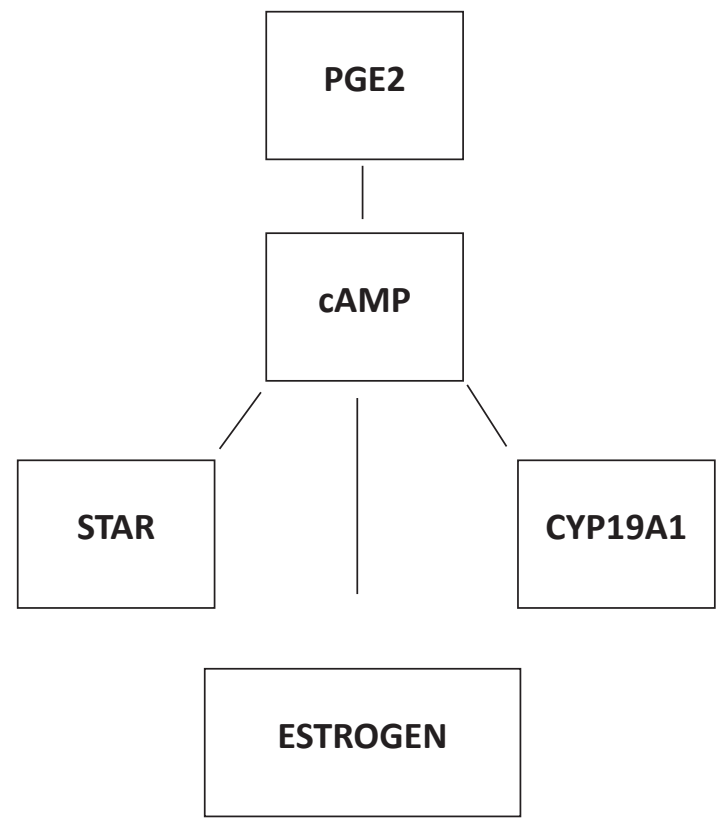

Scheme 1. Relation between Prostoglandin E2 and local hyperestrogenism.

The risk of endometriosis rises up to 7-fold in women who have endometriosis in the first degree re- 
lative compared to the general community. The genetic factors may increase one's predisposition to endometriosis. It is suggested that genetic factors which are responsible for the etiopathogenesis of the endometriosis are multifactorial and polygenic $^{10}$. The genetic predisposition probably increases the tendency of recurrence of endometriosis lesions with the above mechanisms. All of these mechanisms explain implanting, contuinity and growing of the endometriotic cells which are inoculated into the episiotomy scar. Recurring cases of endometriosis are seen because of occurrence of in situ lesion, microscopic metastasis and insufficient surgery ${ }^{11}$.

Endometriotic lesions which develop in the episiotomy scar may invade the anal sphincter and perianal fossa as their size increases ${ }^{12}$. Therefore, early diagnosis and treatment are very important. Invasion to these anatomical structures also intensifies the pain of the patient. The most appropriate treatment in order to prevent recurrence is wide local excision. In this case, although endometriotic nodule was quite deep and close to the anal sphincter fibers, the mass could be excised totally without damaging the anal sphincter fibers.

In addition, according to the current knowledge, episiotomy scar and the materials to be sutured should not be contaminated as much as possible with the blood and debris coming from the uterine cavity and gloves should be changed before episiotomy suturation in cases where cavity should be checked and manually removed. Future studies should be conducted in order to prevent the development of endometriosis on the episiotomy scars.

\section{REFERENCES}

1. Francica G, Giardiello C, Angelone G, et al. Abdominal wall endometrium near caesarean delivery scars. J Ultrasound Med 2003;22(10):1041-7. http://dx.doi.org/10.1007/s00404-015-3756-4

2. Juanqing Li, Yifu Shi, Caiyun Zhou, Jun Lin. Diagnosis and treatment of perineal endometriosis: review of 17 cases. Arch of Gynecol and Obstet 2015;292(6):1295-1299. http://dx.doi.org/10.1007/s00404-015-3756-4

3. Odobasic A, Pasic A, Iljazovic-Latifagic E, et al. Perineal endometriosis: a case report and review of the literature. Tech Coloproctol 2010;14 (1):25-7. http://dx.doi.org/10.1007/s10151-010-0642-8

4. Laadioui M, Alaoui F, Jayi S, et al. Deep perineal endometriosis on episiotomy scar: about a rare case. Pan Afr Med J 2013;16:112.

http://dx.doi.org/10.11604/pamj.2013.16.112.3415. e Collection 2013.

5. Luterek K, Barcz E, Bablok L, Wierzbicki Z. Giant recurrent perineal endometriosis in an episiotomy scar-a case report. Ginekol Pol 2013;84(8):726-9. http://dx.doi.org/10.17772/gp/1631

6. Jain D. Perineal scar endometriosis: a comparison of two cases. BMJ Case Rep 2013;29.pii: bcr2013010051. http://dx.doi.org/10.1136/bcr-2013-010051

7. Gunes M, Kayikcioglu F, Ozturkoglu E, Haberal A. [Incisional endometriosis after cesarean section, episiotomy and other gynecologic procedures]. J Obstet Gynaecol Res 2005;31(5):471-5. http://dx.doi.org/10.1111/j.1447-0756.2005.00322.x

8. Noble LS, Takayama K, Zeitoun KM, et al. Prostaglandin E2 stimulates aromatase expression in endometriosis-derived stromal cells. The Journal of Clinical Endocrinology and Metabolism 1997;82:600-6.

http://dx.doi.org/10.1210/jc.82.2.600

9. Sun HS, Hsiao KY, Hsu CC, et al. Transactivation of steriodogenic acute regulatory protein in human endometriotic stromal cells is mediated by the prostaglandin EP2 receptor. Endocrinology 2003;144:3934-42.

http://dx.doi.org/10.1210/en.2003-0289

10. Nyholt DR, Low SK, Anderson CA, et al. Genome-wide association meta-analysis identifies new endometriosis risk loci. Nat Genet 2012;44(12):1355-9. http://dx.doi.org/10.1038/ng.2445. Epub 2012 Oct 28.

11. Exacoustos C, Zupi E, Amadio A, et al. Recurrence of endometriomas after laparoscopic removal: sonographic and clinical follow-up and indication for second surgery. J Minim Invasive Gynecol 2006;13:281-8. http://dx.doi.org/10.1016/j.jmig.2006.03.002

12. González-Longoria G, Mejía-Ovalle RR, Salinas-Aragón E, et al. Perineal endometriosis with anal external sphincter involvement: a case-report. Rev Gastroenterol Mex 2011;76(2):173-7. 